\title{
Attitudes toward gay and lesbian individuals in Russia: An exploration of the interpersonal contact hypothesis and personality factors
}

\author{
Sharon G. Horne $\mathrm{a}^{\mathrm{a}^{*}}$, Meredith R. Maroney ${ }^{\mathrm{a}}$, \\ Elizaveta A. Zagryazhskaya ${ }^{\mathrm{b}}$, Julie Koven ${ }^{\mathrm{a}}$ \\ ${ }^{a}$ Counseling and School Psychology, University of Massachusetts, Boston, USA \\ ${ }^{\mathrm{b}}$ Faculty of Psychology, Lomonosov Moscow State University, Moscow, Russia \\ *Corresponding author. E-mail: Sharon.Horne@umb.edu
}

Background. Negative attitudes toward Gay, Lesbian, and Bisexual people in Russia are common, and may have become more prevalent due to recent policy changes.

Objective. This study explored whether interpersonal contact and personality characteristics predicted Hateful Attitudes Toward GLB people and Endorsement of GLB Rights.

Design. The design of the study included 154 heterosexual undergraduate students in Moscow and Volgodonsk who were surveyed about their attitudes toward GLB people as well as their personality characteristics assessed with the NEO-FFI.

Results. Results suggested that Moscow students held less hateful attitudes and endorsed greater GLB Rights than Volgodonsk students. Women were also more favorable toward GLB Rights than men. In terms of Hateful Attitudes, having GLB friends or acquaintances was a negative predictor of Hateful Attitudes, while neuroticism and conscientiousness were positive predictors. In conclusion, living in a large urban area, knowing GLB individuals, and low levels of neuroticism and conscientiousness appear to be associated with positive attitudes toward GLB people in Russia, however, personality characteristics and knowing GLB people did not appear to relate to endorsement of GLB Civil Rights.

Conclusion. Current sociopolitical policies such as the propaganda ban, and historical censure of GLB rights during the Soviet era, may impact how "out" GLB Russian people can be, particularly outside of large urban centers, and may reinforce general lack of support for GLB Civil Rights in the Russian population.

Keywords: attitudes, gay, lesbian, bisexual, GLB Rights, personality characteristics, NEO-FFI, interpersonal contact 


\section{Introduction}

Although former Russian President Boris Yeltsin decriminalized male homosexuality in 1993, and homosexuality was removed as an official mental disorder by the Ministry of Health in 1999, gay, lesbian, and bisexual (GLB) sexual orientations and identities remain stigmatized in contemporary Russian society (Khazan, 2013). In the decade following decriminalization, GLB people appeared to disclose their sexual orientation to a greater degree, while non-profit organizations which were focused on GLB rights developed, and in some cases flourished, suggesting important gains for the acceptance of Russian GLB people (Horne, Ovrebo, Levitt \& Franeta, 2010). Currently, however, Russian GLB people find themselves the targets of a wave of anti-GLB policies that have been instituted since Vladimir Putin's reelection in 2012, including the 2013 federal law "For the Purpose of Protecting Children from Information Advocating for a Denial of Traditional Family Values," also referred to as the Propaganda Ban on Non-Traditional Sexual Relations.

This bill effectively renders illegal any actions that equalize same-sex relationships and GLB identities in the presence of minors, including gay pride parades, or which affirm GLB identities or same-sex relationships in person or on the Internet (Elder, 2013; Shkel, 2013). Regional bans on "propaganda of homosexualism" followed suit in areas of Russia ranging from Magadan Oblast in the Far East to Krasnodar Krai in the South. In addition, in 2014, federal restrictions were passed with respect to adoption by single GLB people, or by same-sex couples in countries that permit same-sex marriage. Since same-sex marriage is not legal in Russia, same-sex Russian couples are not allowed to adopt (Human Rights Campaign, 2014).

Russia consistently ranks among the most negative of democratic countries in anti-GLB attitudes (Pew Research Center, 2013). In a cross-national study that asked the question whether same-gender sexuality was "always wrong," $54.2 \%$ of Russian participants endorsed this view in 1998 , while $64.2 \%$ did so a decade later in 2008-a reversal of the global trend toward greater acceptance found in most democracies. In this 2013 Pew study, Russia ranked among the countries showing the least favorable attitudes, with only $8.3 \%$ of the participants reporting that same-gender sexuality was not wrong at all. As recently as 2015 , in a survey of 800 Russians over the age of 18 and living in 46 different regions of the country, $37 \%$ reported that homosexuality is an illness that must be medically treated; $26 \%$ reported that homosexuality is the result of a bad upbringing or promiscuity; and $13 \%$ believed that homosexuality was a result of sexual seduction or abuse (Levada Center, 2015). Only $11 \%$ reported that homosexuality was a sexual orientation from birth that warranted the same rights as a heterosexual orientation. In 2013, in a survey of 1600 respondents, $5 \%$ reported that homosexuals should be liquidated, a Russian euphemism for killing, wiping out, or disposing of people (Levada Center, 2013).

These prevailing negative attitudes do not appear to differ a great deal from the results of earlier research on attitudes toward homosexuality during the Perestroika period, or shortly after Russia became an independent state. According to the late Igor Kon, the country's most noted sexologist, homosexuals were the most stigmatized of all social groups (Kon, 2002). In a poll conducted by the Russian Public Opinion Research Center (VTsIOM) in 1989, with a representative sample 
of people from Russia, $27 \%$ favored "liquidation," and $32 \%$ endorsed isolation for homosexuals. Only $12 \%$ favored "leaving them alone," and a mere $6 \%$ endorsed helping them (Kon \& Riordan, 1993). In a 1994 replication study, the endorsement of liquidation of homosexuals had fallen to $18 \%$, isolation had fallen to $23 \%$, and the percentages for leaving them alone and the desire to help them had risen to 29 and $8 \%$, respectively (Kon 1998).

In 1998, in a survey of the general population, attitudes appeared to be moving in a more accepting direction; only $17.5 \%$ and $14.7 \%$ of respondents endorsed liquidation and isolation, respectively, and a full $40.8 \%$ favored leaving homosexuals alone (VTsIOM poll 1998, as cited in Kon 1998). Despite these attitudinal changes, one-third of those polled considered homosexuality an illness or a result of psychic trauma, and another third viewed it as a depravity or a bad habit; only $18 \%$ considered it to be a valid orientation with the right to exist. Although it is not possible to conduct a strict comparison, due to different sampling methodologies, recent research suggests the percentages of acceptance and stigmatization fall into similar patterns within the current Russian population, perhaps with a slip in affirming attitudes since the 2000s, with the majority of those polled endorsing the view that same-gender sexual relations are unacceptable (Anderson \& Fetner, 2008; Levada Center, 2013; 2015).

As in research in other countries which shows that higher education is positively correlated with greater tolerance to homosexuality (Anderson \& Fetner, 2008), Russian individuals with lower education levels endorse criminal prosecution more than do more highly educated individuals (Levada Center, 2015). Although in many countries, women tend to endorse more positive attitudes towards homosexuality (Anderson \& Fetner, 2008), a gender gap has not been consistently found in Russia; for example, no gap was found in 2013 (Pew Research Center, 2013), although Russian women had been found to endorse greater tolerance toward homosexuality in earlier research (Chervyakov, Kon, \& Shapiro 1993).

However, a consistent pattern of younger people endorsing more positive attitudes has been found. For example, Russian youth were found to have more positive or neutral opinions about homosexuality than negative ones (Chervyakov, Kon, \& Shapiro 1993); more recently, among 18-29 year olds, $21 \%$ endorsed the idea that homosexuality should be accepted vs. $17 \%$ of $30-49$ year olds, and $12 \%$ of those over 50 years of age (Pew Research Center, 2013). Finally, people who live in large urban settings tend to hold more favorable attitudes towards GLB people than those living in rural settings (Dillon \& Savage, 2006); however, to date, we have not found any research that explored this potential divide in Russian attitudes toward homosexuality.

\section{Hypothesis}

\section{Interpersonal contact with GLB individuals}

The interpersonal contact hypothesis suggests that individuals who have at least one gay or lesbian person in their social networks are more likely to have favorable attitudes toward GLB people, compared to those who are not familiar with gay or lesbian people. This relationship has been borne out in numerous research stu- 
dies (Cullen, Wright, \& Allessandri, 2002; Herek, 1996; Herek \& Capitanio, 1996; Herek \& McLemore, 2013). For example, in an analysis of 27 national surveys, it was found that people who know GLB people are much more inclined to support GLB rights, as well as become their allies (Fingerhut, 2011), even after controlling for different types of relationships with GLB people, and for demographic, religious, and political factors (Lewis, 2011).

It does not appear that the interpersonal contact hypothesis has been explored in Russia in depth, and given the small numbers of GLB people who have "come out," it is questionable whether interpersonal contact can be easily assessed. For example, in the Levada Center survey (Levada Center, 2013), only $5 \%$ reported that they had any gay or lesbian acquaintances, with another $4 \%$ refusing to answer. However, if interpersonal contact patterns follow those in other countries, it is likely that Russians who have GLB friends and family members, even if they are a small minority, would have less hateful attitudes, and be in greater support of GLB civil rights.

\section{Personality types: The NEO and attitudes toward homosexuality}

Research has found that people who are less psychologically secure may have more negative attitudes toward others who differ in demographic characteristics, than those who report being more psychologically secure (e.g., Sniderman, Hagerdoorn, \& Prior, 2004). For example, men who endorse characteristics or beliefs that conform to cultural expectations of masculinity expressed in such traits as toughness and antifemininity, are more likely to endorse sexual prejudice against gay men (Barron et al. 2008, Baunach et al. 2010, Herek \& McLemore, 2013; Keiller, 2010, Meaney \& Rye, 2010, Parrott, Adams, \& Zeichner, 2002), than those who do not.

Past research has explored the relationship between personality traits, particularly the Big Five, and political attitudes, including attitudes toward GLB rights. The Big Five personality traits-openness, conscientiousness, agreeableness, neuroticism, and extraversion-have consistently been found to be associated with particular social and political attitudes (Shackelford \& Besser, 2007). For example, research that has investigated the Big Five and political attitudes, shows conscientiousness to have had the strongest positive correlation with conservative political attitudes (Carney et al., 2008; Gerber et al., 2010; Osborne \& Sible, 2015). Meanwhile, openness has often been linked to liberal attitudes, and neuroticism has had a negative relationship with conservativism (Carney et al., 2008; Gerber et al., 2010; Mondak \& Halperin, 2008, Mondak et al., 2010; Osborne \& Sible, 2015). A correlation between extraversion and agreeableness, and political attitudes, has been inconsistent across studies. Political attitudes, namely liberalism or conservativism, are informative when it comes to GLB support and prejudice, as research has demonstrated that those with conservative values are more likely to adhere to social norms, and less likely to endorse GLB rights (Gerber et al., 2010).

Only a few studies have explored the relationship between personality traits and GLB attitudes. Preliminary findings have cohered with the results of studies of political attitudes. Those who scored higher on openness had more positive attitudes towards homosexuality, while those with high conscientiousness were less likely to support LGBT rights (Osborne \& Sible, 2015; Shackelford \& Besser, 
2007). Extraversion has been inconsistent across studies; it has been positively associated with support for LGBT rights in some samples (Osborne \& Sible, 2015), but it has also been positively associated with avoidance of homosexuals in another (Okura, Yamamoto, \& Shigemoto, 2012). Additionally, psychological entitlement - a sense that one deserves more and is entitled to more than others - is positively correlated with low agreeableness (Campbell et al., 2004), and psychological entitlement has been linked to prejudice against "out groups," particularly lesbian women and gay men (Anastasio \& Rose, 2014). Given that personality traits may provide insight into political and GLB attitudes, research in this area is informative for this work.

Our study explored background factors (i.e., age, region, education, gender) and interpersonal contact with GLB individuals, as well as personality factors in relation to attitudes toward gay, lesbian, and bisexual individuals in Russia (both hateful attitudes and attitudes toward GLB rights). The research questions included:

1. Do background factors - including age, region, education, and gender predict Hateful Attitudes and Attitudes Toward GLB Rights?

2. Does interpersonal contact with GLB friends and family predict Hateful Attitudes and Attitudes Toward GLB Rights?

3. Do the Big Five personality dimensions predict Hateful Attitudes and Attitudes Toward GLB Rights?

\section{Method}

Our sample included 154 heterosexual undergraduate students in psychology (136 female and 18 male) who were attending Russian public and private universities. Ages ranged from 17 to 51, with a mean age of 30.3. Seventy-six respondents were from Moscow (population 12.4 million), and 78 were from a small city in the South of Russia, Volgodonsk in the Rostov region, which has approximately 170,000 residents.

\section{Measurements}

Our testing instruments all underwent back and forward translation, and were administered in the same order to all participants. Participants indicated their consent by participating in the research, and no identifying information was collected. Undergraduate students in social science courses in two universities were invited to participate in the study.

Demographic Questions. These items asked for age, gender, region, education, and sexual orientation.

The Lesbian, Gay, and Bisexual Knowledge and Attitudes Scale for Heterosexuals (LGB-KASH; Worthington et al., 2005). This scale is a 28 -item survey, in self-report form, which measures five factors that influence an individual's attitudes or knowledge of GLB individuals: hate (6 items), knowledge (5 items), religious conflict (7 items), GLB Civil Rights (5 items), and Internalized Affirmativeness ( 5 items). The items were measured on a 5-point Likert-type scale (ranging from "1-Very characteristic of me" to "5-Very uncharacteristic of me"). The 
scores of each subscale were added together to create a composite measure. For this sample, only the subscales Hate (reverse coded) (Cronbach alpha $=.83$ ) and GLB Civil Rights (Cronbach alpha $=.71$ ) were included in the study. A sample item from the Hate subscale includes: "GLB people deserve the hatred they receive," and from the GLB Civil Rights subscale: "I think marriage should be legal for same-sex couples."

The NEO Five Factor Inventory (NEO-FFI; Costa \& McRae, 1992). This 60item instrument is an abbreviated version of the 24-item NEO-PI-R, which measures five personality dimensions (neuroticism, extraversion, openness, agreeableness, and conscientiousness), with 12 items included per domain. The NEO-FFI features self-descriptive statements that participants rate on a 5-point Likert type scale (ranging from $1=$ strongly disagree to $5=$ strongly agree). A sample item from the neuroticism scale includes: "When I'm under a great deal of stress, sometimes I feel like I'm going to pieces," and from the conscientiousness scale: "I have a clear set of goals and work toward them in an orderly fashion." Internal consistency values for all scales ranged from .74 to .89 .

Interpersonal Contact Questions. Two interpersonal contact questions explored whether or not participants had close friends, family members, or acquaintances who were gay or lesbian. The responses were combined to create a variable indicating those with no friends, family, or acquaintances, and those with relationships with GLB individuals.

\section{Results}

Table 1 provides the correlations among the major variables, as well as means and standard deviations.

Table 1. Descriptive Statistics and Correlations

\begin{tabular}{|c|c|c|c|c|c|c|c|c|c|c|c|}
\hline & $M$ & SD & 1 & 2 & 3 & 4 & 5 & 6 & 7 & 8 & 9 \\
\hline 1 Age & 30.30 & 7.8 & 1 & & & & & & & & \\
\hline 2 Gender & .12 & .322 & -.001 & 1 & & & & & & & \\
\hline 3 Education & 13.45 & 1.26 & $.390^{* *}$ & +15 & 1 & & & & & & \\
\hline 4 Region & 1.51 & .502 & .031 & $-.17^{\star}$ & $-.30^{* *}$ & 1 & & & & & \\
\hline 5 Int Contact & .33 & .472 & -.142 & -.08 & .022 & $-.409^{* *}$ & 1 & & & & \\
\hline 6 Neurot & 19.32 & 7.79 & .031 & $-.17^{\star}$ & .02 & -.012 & .05 & 1 & & & \\
\hline 7 Conscient & 32.05 & 7.01 & -.071 & $-.23^{* *}$ & -.06 & .093 & -.05 & $-.41^{\star}$ & 1 & & \\
\hline 8 Hate & 16.69 & 8.64 & .087 & .004 & -.15 & $.601^{* *}$ & $-.47^{\star *}$ & .12 & .107 & 1 & \\
\hline 9 GLB Rights & 13.39 & 5.62 & .004 & $-.23^{\star *}$ & .03 & $-.36^{\star \star}$ & $.25^{\star *}$ & -.097 & .088 & $-.42^{\star *}$ & 1 \\
\hline
\end{tabular}

In terms of Hateful Attitudes, the model (see Table 2) was significant: $F(7$, $131)=18.57 ; R^{2}=.498 ; p=.001$. The respondent's region made a significant independent contribution in the set of background variables $(\beta=.616 ; p=.001)$, with 
the less urban setting of Volgodonsk region predicting greater Hateful Attitudes. In terms of the next step, interpersonal contact with GLB people made a substantial incremental contribution to Hate $\left(\Delta R^{2}=.05 ; p=.001\right)$, indicating that the more interpersonal contact a person had with close friends, family, and colleagues who were GLB, the less Hate they endorsed $(\beta=-.248 ; p=.001)$. In terms of personality factors, both neuroticism $(\beta=.238 ; p=.001)$ and conscientiousness $(\beta=.195$; $p=.009)$ were predictive of Hateful Attitudes $\left(\Delta R^{2}=.06 ; p=.001\right)$; other personality factors did not predict hateful attitudes.

Table 2. Hierarchical Regression of Hate on Background Variables and Interpersonal Contact $(\mathrm{N}=139)$

\begin{tabular}{lccccc}
\hline \multicolumn{1}{c}{ Variable } & $B$ & $S E(B)$ & $\beta$ & $P$ & $R^{2}$ \\
\hline Step 1 & & & & & .385 \\
$\quad$ Age & .088 & .080 & .081 & .271 & \\
Gender & 2.88 & 1.77 & .111 & .105 & \\
Education & -.187 & .527 & -.027 & .723 & \\
Region & 10.6 & 1.23 & .616 & $.000^{*}$ & \\
Step 2 & & & & & .434 \\
Age & .56 & .078 & .051 & .472 & \\
Gender & 1.87 & 1.73 & .072 & .281 & \\
Education & -.230 & .508 & -.034 & .651 & \\
Region & 8.71 & 1.30 & .506 & $.000^{*}$ & \\
Interpersonal Contact & -4.55 & 1.32 & -.248 & $.001^{*}$ & \\
Step 3 & & & & & .498 \\
Age & .106 & .077 & .095 & .169 & \\
Gender & 3.80 & 1.83 & .143 & $.040^{*}$ & \\
Education & -.400 & .507 & -.056 & .432 & \\
Region & 9.04 & 1.27 & .519 & $.000^{*}$ & \\
Interpersonal Contact & -4.17 & 1.29 & -.227 & $.002^{*}$ & \\
Neuroticism & .261 & .078 & .238 & $.001^{*}$ & \\
Conscientiousness & .241 & .90 & .195 & $.009^{*}$ & \\
\hline
\end{tabular}

The model exploring predictors of views of GLB Civil Rights (see Table 3) was also significant: $F(7,131)=7.205 ; R^{2}=.28 ; p=.001$. In terms of background variables, both female gender $(\beta=-.299 ; p=.001)$ and Moscow region $(\beta=-.422$; $p=.001$ ) independently and positively predicted greater endorsement of GLB Rights. However, interpersonal contact did not significantly contribute to the variance above and beyond the background variables $\left(\Delta R^{2}=.04 ; p=.297\right)$. Finally, the addition of the personality factors did not contribute to the model, although neuroticism approached significance $(\beta=-.162 ; p=.061)$, suggesting that there may be a relationship between neuroticism and lack of support for GLB Rights. 
Table 3. Hierarchical Regression of GLB Civil Rights on Background Variables and Interpersonal Contact $(\mathrm{N}=139)$

\begin{tabular}{|c|c|c|c|c|c|}
\hline Variable & B & SE(B) & $\beta$ & $p$ & $R^{2}$ \\
\hline Step 1 & & & & & .261 \\
\hline Age & .043 & .059 & .061 & .464 & \\
\hline Gender & -5.09 & 1.31 & -.299 & $.000^{*}$ & \\
\hline Education & -.391 & .390 & -0.88 & .318 & \\
\hline Region & -4.76 & .907 & -.422 & $.000^{*}$ & \\
\hline Step 2 & & & & & .222 \\
\hline Age & .051 & .060 & .071 & .394 & \\
\hline Gender & -4.85 & 1.33 & -.285 & $.000^{*}$ & \\
\hline Education & -.381 & .390 & -.085 & .330 & \\
\hline Region & -.432 & .999 & -.383 & $.000^{*}$ & \\
\hline Interpersonal Contact & 1.07 & 1.01 & .088 & .297 & \\
\hline Step 3 & & & & & .278 \\
\hline Age & .032 & .060 & .045 & .590 & \\
\hline Gender & -5.72 & 1.417 & -.333 & $.000^{*}$ & \\
\hline Education & -.489 & .393 & -.106 & .261 & \\
\hline Region & -.479 & .986 & -.425 & $.000^{*}$ & \\
\hline Interpersonal Contact & .921 & .999 & .077 & .358 & \\
\hline Neuroticism & -.115 & .061 & -.162 & .061 & \\
\hline Conscientiousness & .003 & .070 & .004 & .968 & \\
\hline
\end{tabular}

\section{Discussion}

Given that Moscow is the main urban center in Russia and the largest city in Europe (with more than 12.2 million residents-United Nations, 2016), and boasts a diverse population and metropolitan culture, it is not surprising that Muscovites tended to have more positive attitudes towards GLB people, and to endorse greater civil rights for GLB individuals. Moscow participants $(M=11.45 ; S D=5.33)$ had lower scores on the Hate subscale than Volgodonsk participants $(M=21.79$; $S D=8.18 ; t(152)=-9.273 ; \mathrm{p}=.001)$, and endorsed greater support for GLB Civil Rights $(M=15.43 ; S D=5.08)$ than Volgodonsk participants $(M=11.40 ; S D=5.42$; $t(152)=4.762 ; \mathrm{p}=.001$.) Indeed, Moscow participants reported a significantly higher percentage of GLB friends, family, and acquaintances as compared to the Volgodonsk residents $(x 2=24.09 ; \mathrm{df}=1, \mathrm{p}<.001)$.

Although Moscow appears to be a more affirming city for GLB people as compared to Volgodonsk, the anti-propaganda bans have resulted in an atmosphere of fear and anxiety among GLB people, which also prevents GLB people from disclosing their sexual orientations (Horne, Wheeler, Maroney, \& Peters, 2017). In addition, the lack of non-discrimination policies means that GLB people have no 
protection to be "out" in the workplace, or in their schools or universities (Horne, 2014), and policies that restrict public events such as the ban on Pride parades in Moscow for 100 years (through 2112) are certainly going to continue to clamp down on GLB self-disclosure and self-determination (Clemons, 2012).

Although in some countries gender has been found to lead to different attitudes toward GLB people, with women endorsing more favorable attitudes (e.g., Ahrold \& Meston, 2010; Kite \& Whitley, 1996), in our study, as in international research overall, gender was not a significant predictor of hateful attitudes (Pew Research Center, 2013).

However, in terms of endorsement of GLB rights, gender was a significant predictor, with women expressing greater support for GLB Civil Rights $(M=13.86$; $S D=5.54)$ than men $(M=9.83 ; S D=4.99, t(152)=2.92 ; \mathrm{p}=.004)$. Men's endorsement of sexual prejudice appears to be multifaceted; according to Herek and McLemore (2013), some heterosexual men may be responding in a sexually prejudicial way due to anxiety related to their internal same-sex attractions or desires, even if that feeling is not conscious. Other men may experience anxiety or fear due to perceptions that they may not be meeting cultural expectations for men, and may engage in sexual prejudice toward GLB people to reduce these emotions and enhance their inclusion within socially proscribed norms for masculinity.

Given these potential factors, it is not surprising that, in light of the broad negative stereotyping of gay men in Russia as sexual predators, and the history of criminalization of same-sex male sexual behavior (vs. the medicalization of women's same-sex sexuality) (Essig, 1999; Healey, 2004), there would be gender differences with respect to structural changes for GLB rights. In addition, women are more likely to become allies of GLB people (Herek \& McLemore, 2013), and therefore may be more likely to endorse policy-related changes.

The interpersonal contact hypothesis, which suggests that the more GLB individuals a person knows, the more positive the attitudes towards GLB people, was again shown to be a significant predictor for Hateful Attitudes (Herek \& Glunt, 1993; Herek \& Capitanio, 1996; Horne, Rice, \& Israel, 2004). After controlling for age, region, gender, and education, knowing GLB individuals significantly and negatively predicted Hateful Attitudes. This finding suggests that Russian GLB communities would benefit from greater acceptance and support for their rights if they had better safeguards for individuals to be "out," and therefore "known" as being GLB. While same-sex sexual behavior is no longer illegal, there are no state-wide protections based on sexual orientation or gender identity; therefore, few GLB individuals have the security to be "out" in their workplaces, families, and communities. This is obviously a paradox because, on the one hand, an open and inclusive atmosphere is needed in order for GLB people to "come out," thus allowing heterosexual people to get to know them, but knowing GLB individuals is key to creating that very atmosphere of support for increased GLB rights. In light of our analysis of the experiences of GLBT individuals living in Russia during a time of seeming openness and forward motion, we caution that such movement may be compromised due to shifting Russian sociopolitical contexts (Horne, et al., 2009).

Knowing GLB individuals, however, did not predict endorsement of GLB Rights. This finding suggests that people may be able to hold positive feelings and 
thoughts about GLB people they know, but at the same time hold reservations about whether GLB people should have equal rights as heterosexual people. This finding is not surprising, given the formal propaganda bans and anti-GLB rhetoric prevalent in Russia, as well as the ways that stereotypes are reinforced (Herek, 1996). For example, people with GLB friends and acquaintances may reason that their GLB friends are the exception to the stereotypes of GLB people (e.g., their friends who are in a same-sex relationship have a stable relationship), but that GLB people overall fit the stereotypes (GLB people don't maintain healthy relationships), and therefore, are undeserving of equivalent GLB rights and marriage.

Two dimensions of personality - neuroticism and conscientiousness - predicted Hateful Attitudes toward GLB people. Neuroticism assesses facets of hostility and anxiety, and suggests that those who are experiencing greater vulnerability to stress and self-consciousness may more readily accept stereotypes and feel threatened by GLB people. The degree of neuroticism approached significance with the endorsement of GLB Rights, with lower neuroticism predicting a more positive attitude towards GLB people having rights. This finding also makes sense given that those who experience greater anxiety and vulnerability to stress, may be less likely to desire structural changes that may modify society's social and political norms.

Conscientiousness, which has been found to be associated with more conservative attitudes, as well as lack of support for GLB rights (Gerber et al., 2010), predicted Hateful Attitudes in this sample. The tendency toward orderliness, duty, and self-discipline characterized by this personality dimension corresponds with more hateful attitudes towards GLB people, who often are stereotyped in Russia as a social group that does not follow established traditional norms. The emphasis placed on the importance of fulfilling moral obligations, which characterizes conscientiousness, is congruent with negative attitudes towards GLB people. This is due to the propagation of myths and stereotypes suggesting that GLB people are immoral, or promote destabilizing "non-traditional family values and sexual relationships." Interestingly, the degree of conscientiousness in this sample was not found to correlate with endorsement of GLB Rights.

\section{Limitations \& future research}

Although every effort was made to conduct thorough back and forward translations of the testing measures used in this study, the fact that, with the exception of the NEO-FFI, they are not commonly used in Russia, may mean the instruments were limited in terms of their internal validity. The internal consistency of the measures was good, suggesting that they were assessing the intended constructs; however, extensive assessment and analysis of these measures were not conducted to assure face and construct validity. The surveys were also based on self-reporting, and limited to university students, who are more highly educated than the general population; therefore, the sample was relatively uniform in age and education, reducing the variability of these factors. Finally, these data were collected prior to the passage of the 2013 Propaganda Ban, and therefore attitudes may have been less Hateful or more supportive of GLB Rights than present-day attitudes. 
Still, the mean score for the Hateful Attitudes subscale ( $M=16.69$ with a range of 1-25, with 25 indicating the most Hateful Attitudes) in the Russia sample is strikingly higher than the reported mean score for this subscale in U.S. samples (e.g., $M=1.39$ with a range of 1-7). These findings correspond to the results of the recent survey of attitudes by the Levada Center $(2013$; 2015) and the Pew Research Center (2013), which found the majority of those surveyed holding negative attitudes towards GLB individuals. Finally, in terms of endorsement of GLB Rights, participants on average were not in favor of GLB Rights (e.g., $M=13.39$ with a range of $1-25$, with higher scores indicating greater endorsement of rights) as compared to U. S. samples (e.g., 4.94 for a range of 1-7). Given the combination of negative attitudes and lack of support for GLB rights, it is not surprising that basic protections for GLB individuals have not advanced in Russia, and in fact, have regressed in many ways.

Attitudes toward homosexuality are often associated with religious affiliation (Olson, Cadge \& Harrison, 2006), as well as religious orientation, orthodoxy, and fundamentalism (Kirkpatrick, 1993). However, Russia and other former communist countries provide a more complex relationship due to the lack of religiosity during the Soviet period. For example, Russia ranks as one of the least religious countries in the world (Khazan, 2013). Yet, the influence of the Russian Orthodox Church is increasing, and it remains steadfast in its opposition to same-sex relationships. Future research on attitudes may be fruitful if, rather than testing for religiosity, it explores support for the Russian Orthodox Church, or whether individuals support the social values of the Church, independent of whether they practice religion or attend services. It may also be useful to explore the strategies and supports which heterosexual people with favorable attitudes toward GLB people develop and maintain in the face of anti-GLB media and characterizations. Finally, given the political climate, research on the impact of minority stress, in particular internalized homonegativity, on the mental health of GLB individuals in Russia is warranted.

\section{Conclusion}

This study explored the relationship between interpersonal contact and personality factors, and the endorsement of both Hateful Attitudes toward GLB individuals and GLB Rights in Russia. At the present moment, Hateful Attitudes are prevailing, and GLB Rights are stagnant. Many Russian GLB people face violence and stigma on a regular basis due to their sexual orientation. As Anderson and Fetner (2008, p. 955) have suggested based on their analysis of 35 countries, "cultural characteristics, which have less to do with economic development than with a lack of social trust related to Communist oppression, may be responsible for less tolerant attitudes." Although it seemed that GLB rights in Russia might have progressed in a way similar to that in other states that engaged in democratic reforms after the dissolution of the Soviet system, it appears more likely that there is a carry-over of a lack of social trust, which has even grown under the current political system. This pattern of Hateful Attitudes and lack of Support for GLB Rights does not bode well for the physical and psychological well-being of Russian GLB individuals, although living in urban areas and knowing GLB individuals offers hope to reduce GLB-related stigma. 


\section{References}

Ahrold, T.K. \& Meston, C.M. (2010). Ethnic differences in sexual attitudes of US college students: Gender, acculturation, and religiosity factors. Archives of Sexual Behavior, 39, 190-202. doi: 10.1007/s10508-008-9406-1

Anastasio, P.A. \& Rose, K.C. (2014). Beyond deserving more: Psychological entitlement also predicts negative attitudes toward personally relevant out-group. Social Psychological and Personality Science, 5(5), 593-600. doi: 10.1177/1948550613519683

Barron, J.M., Struckman-Johnson, C., Quevillon, R., \& Banka, S.R. (2008). Heterosexual men's attitudes toward gay men: A hierarchical model including masculinity, openness, and theoretical explanations. Psychology of Men \& Masculinity, 9(3), 154-166. doi: 10.1037/15249220.9.3.154

Baunach, D.M., Burgess, E. O., \& Muse, C.S. (2010). Southern (dis)comfort: Sexual prejudice and contact with gay men and lesbians in the South. Sociological Spectrum, 30(1), 30-64. doi:10.1080/02732170903340893

Campbell, W.K., Bonacci, A.M., Shelton, J., Exline, J.J., \& Bushman, B.J. (2004). Psychological entitlement: Interpersonal consequences and validation of a self-report measure. Journal of Personality Assessment, 83(1), 29-45. doi: 10.1207/s15327752jpa8301_04

Carney, D.R., Jost, J.T., Gosling, S.D., \& Potter, J. (2008). The secret lives of liberals and conservatives: Personality profiles, interaction styles, and the things they leave behind. Political Psychology, 29, 807-40. doi: 10.1111/j.1467-9221.2008.00668.x

Chervyakov, V., Kon, I., \& Shapiro, V.D. (1993). Teenagers and sex: Lost illusions. Ogonyok, 2, $22-25$.

Clemons, S. (2012, June 8). Not the Onion: Moscow bans gay pride parades for next 100 years. The Atlantic. Retrieved from https://www.theatlantic.com/international/archive/2012/06/ not-the-onion-moscow-bans-gay-pride-for-next-100-years/258296/

Costa, P.T., Jr., \& McCrae, R.R. (1992). Normal personality assessment in clinical practice: The NEO Personality Inventory. Psychological Assessment, 4, 5-13. doi: 10.1037//10403590.4.1.5

Derogatis, L.R., Rickels, K., \& Roch, R.F. (1976). The SCL-90 and the MMPI: A step in the validation of a new self-report scale. British Journal of Psychiatry, 128(3), 280-289. doi: 10.1192/ bjp.128.3.280

Essig, L. (1999). Queer in Russia: A story of sex, self, and the other. Durham, NC: Duke University Press.

Fingerhut, A. (2011). Straight allies: What predicts heterosexuals' alliance with the LGBT community? Journal of Applied Social Psychology, 41, 2230-2248. doi: 10.1111/j.1559-1816 .2011.00807.x

Gerber, A.S., Huber, G.A., Doherty, D., Dowling, C.M., \& Ha, S.E. (2010). Personality and political attitudes: Relationships across issue domains and political contexts. The American Political Science Review, 104(1), 111-13. doi: 10.1017/S0003055410000031

Healey, D. (2004). Bolshevik medicine and Russia’s sexual revolution. Retrieved from: www. iisg.nl/womhist/healey.doc

Herek, G.M. \& Capitanio, J.P. (1996). "Some of my best friends": Intergroup contact, concealable stigma, and heterosexuals' attitudes toward gay men and lesbians. Society for Personality and Social Psychology, 22(4), 412-424. doi: 10.1177/0146167296224007

Herek, G.M. \& Glunt, E.K. (1993). Interpersonal contact and heterosexuals' attitudes toward gay men: Results from a national survey. The Journal of Sex Research, 30(3), 239-244. doi: $10.1080 / 00224499309551707$

Herek, G.M. \& McLemore, K.A. (2013). Sexual prejudice. Annual Review of Psychology, 64, 30933. doi: 10.1146/annurev-psych-113011-143826 
Horne, S., Rice, D.N., \& Israel, T. (2004). Heterosexual student leader attitudes regarding lesbian, gay, and bisexual students. NASPA Journal, 41(4), 760-772. doi: 10.2202/0027-6014.1398

Horne, S.G., Ovrebo, E., Levitt, H.M., \& Franeta, S. (2009). Leaving the herd: The lingering threat of difference for same-sex identities in post-communist Russia. Sexuality Research and Social Policy, 6, 108-122. doi: 10.1525/srsp.2009.6.2.88

Horne, S.G. (2014). My country, my closet: The role of psychology in the growing international divide over GLBTQ Rights. Psychology in Action: APA's Committee on International Relations in Psychology, 4-7. Retrieved from http://www.apa.org/international/pi/2014/06/ international-glbtq.aspx

Horne, S.G., Wheeler, E., Maroney, M., \& Peters, S. (2017). The development of international LGBTQ activists. Unpublished manuscript.

Human Rights Campaign. (2014). Russia officially bans LGBT international adoption. Retrieved from: http://www.hrc.org/blog/russia-officially-implements-anti-lgbt-international-adoption-ban

Keiller, S.W. (2010). Masculine norms as correlates of heterosexual men's attitudes toward gay men and lesbian women. Psychology of Men \& Masculinity, 11(1), 38-52. doi: 10.1037/ a 0017540

Khazan, O. (2013, June 12). Why is Russia so homophobic? Communist-era justifications for bigotry don't make sense anymore. What's behind lawmakers' opposition to gays? The Atlantic. Retrieved from https://www.theatlantic.com/international /archive/2013/06/why-isrussia-so- homophobic/276817/?utm_source=eb

Kite, B.E. \& Whitley, M.E. (1995). Sex differences in attitudes toward homosexuality: A comment on Oliver and Hyde (1993). Psychological Bulletin, 117(1), 146-154. doi: 10.1037/0033-2909. 117.1.146

Kon, I. (1993). Identity Crisis and Postcommunist Psychology. Symbolic Interaction 16(4), 395405. doi: 10.1525/si.1993.16.4.395

Kon, I. (1995). The sexual revolution in Russia: From the age of the czars to today. New York: The Free Press.

Kon, I. (1998). Moonlight Love: Changing Public Opinion. Accessed April 24, 2004. Retrieved from: http://www.gay.ru/english/history/kon/change.htm

Kon, I.S. (2003). Lunnyj svet na zare. Liki i maski odnopoloj ljubvi [Faces and masks of same sex love. Moonlight at dawn]. Moscow: Olymp.

Kon, I. \& Riordan, J. (1993). Sex and Russian Society. Bloomington: Indiana University Press.

Lewis, G.B. (2011). The friends and family plan: Contact with gays and support for gay rights. Public Management and Policy Faculty Publications, 12, 1-45. doi: 10.1111/j.1541-0072. 2011.00405.x

Meaney, G.J. \& Rye, B.J. (2010). Gendered egos: Attitude functions and gender as predictors of homonegativity. Journal of Homosexuality, 57(10), 1274-1302. doi: 10.1080/00918369. 2010.517074

Mondak, J.J. \& Halperin, K.D. (2008). A framework for the study of personality and political behaviour. British Journal of Political Science 38(2), 335-62. doi: 10.1017/S0007123408000173

Mondak, J.J., Hibbing, M.V., Canache, D., Seligson, M.A., \& Anderson, M.R. (2010). Personality and civic engagement: An integrative framework for the study of trait effects on political behavior. American Political Science Review 104(1), 85-110. doi: 10.1017/ S0003055409990359

Okura, M., Yamamoto, A., \& Shigemoto, T. (2012). P-621. Personality traits influence attitude towards homosexuals among Japanese adolescents. European Psychiatry, 27(1), 1. doi: $10.1016 /$ S0924-9338(12)74788-0 
Osborne, D. \& Sible, C.G. (2015). Within the limits of civic training: Education moderates the relationship between openness and political attitudes. Political Psychology, 36(3), 295-313. doi: $10.1111 /$ pops. 12070

Parrott, D.J., Adams, H.E., \& Zeichner, A. (2002). Homophobia: Personality and attitudinal correlates. Personality and Individual Differences, 32, 1269-1278. doi: 10.1016/s0191-8869(01)00117-9

Pew Research Center. (2013, June 4). The global divide on homosexuality: Greater acceptance in more secular and affluent countries. Retrieved from http://www.pewglobal.org/2013/06/04/ the-global-divide-on-homosexuality

Shackelford, T.K. \& Besser, A. (2007). Predicting attitudes toward homosexuality: Insights from personality psychology. Individual Differences Research, 5(2), 106-114. Retrieved from http://www.idr-journal.com

Sniderman, P.M., Hagendoorn, L., \& Prior, M. (2004). Predisposing factors and situational triggers: Exclusionary reactions to immigrant minorities. American Political Science Review, 98(1), 35-50. doi: 10.1017/s000305540400098x

United Nations, Department of Economic and Social Affairs, Population Division (2016). The World's Cities in 2016. Data Booklet (ST/ESA/ SER.A/392). Retrieved from http://www. un.org/en/development/desa/population/publications/pdf/urbanization/the_worlds_cities_in_2016_data_booklet.pdf

Worthington, R.L., Dillon, F.R., \& Becker-Schutte, A.M. (2005). Development, reliability, and validity of the lesbian, gay, and bisexual knowledge and attitudes scale for heterosexuals (LGB-KASH). Journal of Counseling Psychology, 52(1), 104-118. doi: 10.1037/0022-0167. 52.1.104

The Moscow Times (January 31, 2007). Luzhkov condemns gays as "Satanic." Retrieved from http://larussophobe.wordpress.com/2007/01/31/luzhkov-condemns-gays-as-satanic

Original manuscript received March 29, 2017 Revised manuscript accepted May 23, 2017 First published online June 30, 2017 